\title{
Comparison between human and rat TMJ: anatomic and histopathologic features ${ }^{1}$
}

\author{
Comparação entre a ATM humana e de ratos: achados anatômicos e histopatológicos
}

\author{
Gabriela Granja PortoI, Belmiro Cavalcanti do Egito Vasconcelos ${ }^{\mathrm{II}}$, Emanuel Sávio de Souza Andrade ${ }^{\mathrm{III}}$, Valdemiro Amaro \\ Silva-Junior ${ }^{\mathrm{IV}}$ \\ ${ }^{I}$ Master, Fellow PhD degree, Department of Oral and Maxillofacial Surgery, UPE, Recife-PE, Brazil. \\ ${ }^{\text {II }} \mathrm{PhD}$, Full Professor, Department of Oral and Maxillofacial Surgery. Director of the PhD Program in Oral and Maxillofacial Surgery, UPE, Recife-PE, \\ Brazil. \\ ${ }^{\text {III }} \mathrm{PhD}$, Full Professor, Department of Pathology, UPE, Recife-PE, Brazil. \\ ${ }^{\text {IV }} \mathrm{PhD}$, Full Professor, Department of Veterinary Histology, Federal Rural University of Pernambuco, Recife-PE, Brazil.
}

\begin{abstract}
Purpose: To describe and evaluate normal rat temporomandibular joints from anatomic and histopathologic point of view and make a comparison between this joint in rats and humans. Methods: Twelve male adult Wistar rats (12 same side joints) were used in this procedure. The following anatomical structures were histologically evaluated in a qualitative fashion: condyle, disc, temporal bone, retrodiscal tissue and synovia. The macroscopical and microscopic study of the human TMJ was based on the current literature. Results: The TMJ is surrounded by a thin capsule, consisting of fibrous tissue, and a synovial lining. The mandibular angle has a prominent shape. The glenoid fossa is flat, with no eminences. Histologically, the TMJ is composed of different tissues that comprise the mandibular head, mandibular fossa and fibrocartilaginous disc. A layer of hyaline cartilage covers the articulating cortical condyle and temporal bone. Conclusion: Morphologically and histologically, the articular structure of rats is, on the whole, similar to that of humans. In these animals there is no articular eminence.
\end{abstract}

Key words: Temporomandibular Joint. Anatomy, Comparative. Animal Experimentation. Rats.

\section{RESUMO}

Objetivo: Descrever e avaliar a articulação temporomandibular de ratos sob o aspecto anatômico e histológico e realizar uma comparação entre esta articulação e a de humanos. Métodos: Foram utilizados doze ratos adultos Wistar (12 articulações do mesmo lado). As seguintes estruturas anatômicas foram avaliadas de forma qualitativa: côndilo, disco, osso temporal, tecido retrodiscal e sinóvia. O estudo macroscópico e o microscópico da ATM humana foram baseados na literatura atual. Resultados: A ATM é envolvida por uma fina cápsula, formada por tecido fibroso e cobertura sinovial. O ângulo mandibular é proeminente. A fossa glenoide é rasa, sem eminência articular. De acordo com os achados histológicos, a ATM é composta por diferentes tecidos, são eles a cabeça da mandíbula, a fossa mandibular e o disco fibrocartilaginoso. Uma camada de cartilagem hialina recobre a superfície articular do côndilo e do osso temporal. Conclusão: De acordo com os achados morfométricos e histológicos, a estrutura articular em ratos é, no geral, similar a articulação humana. Exceto que nesses animais não há eminência articular.

Descritores: Articulação Temporomandibular. Anatomia Comparada. Experimentação Animal. Ratos.

${ }^{1}$ Research performed at Post-Graduate Program, Oral and Maxillofacial Surgery, University of Pernambuco (UPE), Recife, Brazil.

\section{Introduction}

The human temporomandibular joint (TMJ) is a group of anatomic structures that, with a special group of muscles, is responsible for the movement of the mandible during mastication. It consists of the condylar process of the mandibular ramus, the mandibular fossa of the temporal bone, a thin articular disc, and a loose joint capsule, which is strengthened by a fibrous lateral ligament ${ }^{1}$. This joint, which is classified as a hinge-sliding joint, has a unique structure and function as compared with other diarthrodial joints ${ }^{2}$.

Innumerous diseases, such as neoplasias, trauma, ankylosis and degenerative diseases may affect the TMJ and lead to the loss of its structures. For all these diseases there are specific treatments, each of which has a wide range of success. As a result there is always a need for progress in the treatment of some of these diseases. Furthermore much of the research in this area cannot be done on humans for ethical reasons. Studies in vitro and 
in animal models may be used for this purpose ${ }^{3}$. In particular, rats may be used since they are easy to handle and inexpensive to maintain in a bioterium, making them a convenient animal for use in experimental studies, giving rise to new ideas in the quest for new treatments for TMJ diseases.

However it is not known how similar the TMJ of the rat is to the human TMJ, which is important for the validation of the studies, despite the realization that these studies cannot be extrapolated to humans because of species differences. Thus, considering that there is no publication in the literature reviewed on anatomic and histopathological characteristics of the rat's TMJ, the aim of this study is to describe and evaluate normal rat joints from this perspective and make a comparison between this joint in rats and humans.

\section{Methods}

\section{Macroscopical procedure}

Twelve male adult Wistar rats (12 same side joints) were used in this procedure. They were killed using $0.1 \mathrm{ml}$ intra-cardiac potassium chloride, after general anesthesia by muscular injection of ketamine and xylazine diluted $1: 1$ in a dose of $0.1 \mathrm{ml}$ per $100 \mathrm{~g}$ of weight. Dissection was then performed, using a surgical instrument, starting from the external surface, observing all anatomic structures related to the TMJ. The following tissues were removed: skin, subcutaneous tissue, blood vessels, nerves, parotid gland, masseter muscle, temporal muscle and adipose tissue. Sagittal and coronal observations were made in order to analyze the relationship of the superior, posterior and superoposterior surfaces. It is important to mention that a judicious dissection of the unilateral joint is possible when the mandibles are separated through the fibrous symphysis, since the incisor teeth of these animals are positioned across the mandible body.

The macroscopical study of the human TMJ was based on the current literature ${ }^{1,2,4}$.

\section{Microscopic procedure}

The joints were fixed with $10 \%$ formaldehyde solution for $24 \mathrm{~h}$ and were decalcified in a solution of 5\% nitric acid for about 7 days. Semi-serial sections 5 - $\mu$ m thick were cut in the sagittal plane and stained with hematoxylin and eosin.

The following anatomical structures were histologically evaluated in a qualitative fashion: condyle, disc, temporal bone, retrodiscal tissue and synovia.

The microscopic study of the human TMJ was based on the current literature ${ }^{1,2,4}$.

\section{Results}

\section{Anatomic considerations of the TMJ}

The TMJ is surrounded by a thin capsule, consisting of fibrous tissue, and a synovial lining. The capsule stretches from the edge of the mandibular fossa to the neck of the condyle. The articular space is separated into superior discotemporal and inferior discomandibular spaces. After dissection, it was observed that the anatomic components of the external surface, from the most superficial to the deepest region, were the following: skin, subcutaneous tissue, lymphatic ganglia, parotid gland, superficial temporal artery, facial and transverse facial arteries and masseter and temporal muscles (Figure 1).

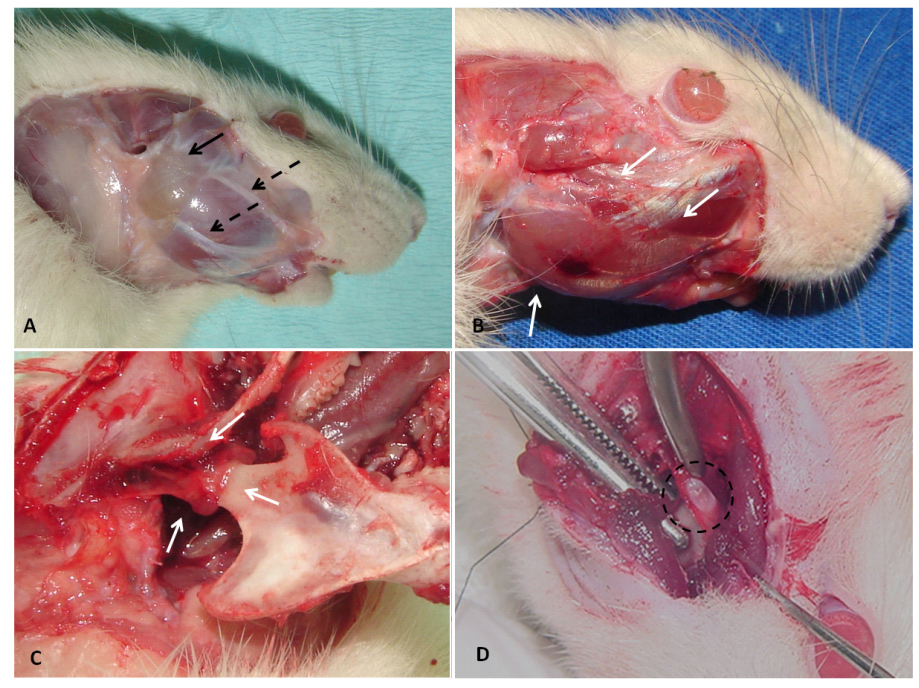

FIGURE 1 - Macroscopical evaluation of the soft tissue. A. Parotid gland (black arrow) and facial nerve (traced black arrow). B. Masseter muscle. C. TMJ capsule. D. Articular disc

After removing the soft tissues, it was observed the shape and size of the anatomical structures such as the zygomatic arch, condyle, mandibular angle and temporal bone; as well as the relationship between them (Figure 2). The mandibular angle has a prominent shape (Figure 2A). The position of the condyles is divergent according to the axial axis (Figure 2B). The glenoid fossa is flat, with no eminences (Figure 2C).
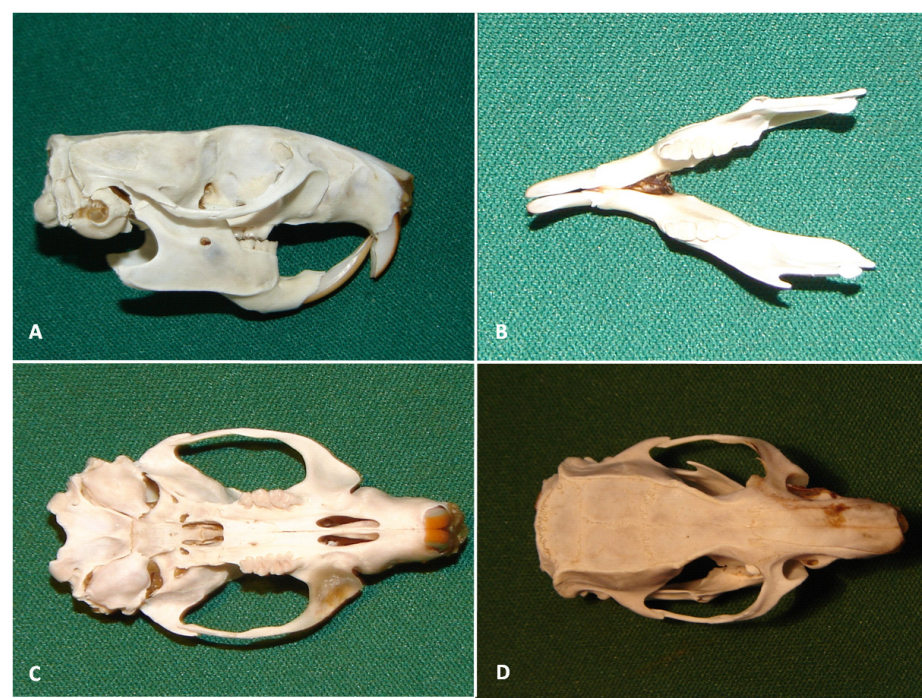

FIGURE 2 - Macroscopical evaluation of the hard tissue. A. Lateral view of the TMJ complex. B. Superior view of the mandible. C. Inferior view of the glenoid fossa. D. Superior view of the TMJ complex 


\section{Histopathologic features}

Histologically, the TMJ is composed of different tissues that comprise the mandibular head, mandibular fossa and fibrocartilaginous disc (Figure 3). A layer of hyaline cartilage covers the articulating cortical condyle and temporal bones (Figure $3 \mathrm{~B}-\mathrm{C}$ ). An interposed fibrocartilaginous disc has a biconcave morphology (Figure 3A). The anterior and posterior ridges of the disc are termed anterior and posterior bands and are longer in the anteroposterior dimension than in the mediolateral. The posterior band blends with highly vascularized, loose connective tissue, known as the bilaminar zone, located in the retrodiscal space (Figure 3D).

\section{$\underline{\text { Condyle }}$}

An area comprising a thick layer of cartilage, mainly of the hyliane type, with layers of superimposed condrocytes that mature as far as the area of transition with the bone tissue, is observed on the articular surface of the mandibular condyle (Figure 3B).

\section{Temporal bone}

As with the articular surface of the condyle, there is a fibrous layer that increases in thickness from an anterior to a posterior position on the articular surface of the temporal bone. There are also layers of condrocytes superimposed but in smaller numbers than on the condyle (Figure 3C).

\section{$\underline{\text { Articular disc }}$}

The articular disc is biconcave, being less thick in the central area; and is made up of fibrous connective tissue. It divides the articular joint into two compartments: superior and inferior (Figure 3A).

In all specimens the anatomic and histopathological characteristics were similar.

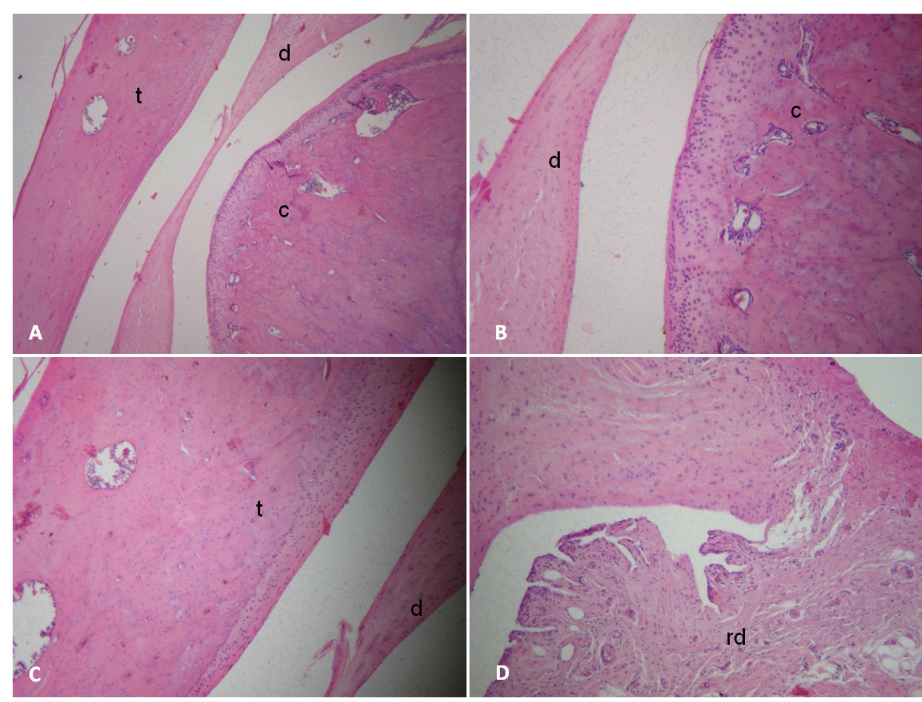

FIGURE 3 - Microscopical evaluation. A. Overall view of the TMJ, with an interposed biconcave disc. B. Articular surface of the condyle. C. Articular surface of the temporal bone. D. Aspect of the retrodiscal region ( $\mathrm{c}=$ condyle; $\mathrm{d}=$ disc; $\mathrm{t}=$ temporal bone; $\mathrm{rd}=$ retrodiscal tissue)

\section{Discussion}

There are several diseases that may attack the TMJ and lead to the loss of its structures, such as neoplasms, trauma, ankylosis, degenerative diseases and others, all of which may require treatment.

If there is a need for reconstruction of the TMJ, autogenous tissue and alloplastic material may be used. However, neither of the treatments is ideal, since both have their drawbacks ${ }^{1}$. Thus, studies dealing with the surgical treatment of diseases of the TMJ need to be conducted for the purpose of producing fresh ideas on innovative treatments. Many of these may certainly be performed on animals.

Innumerous species may be used for this purpose, such as monkeys, rabbits, sheep, goats and minipigs ${ }^{5}$. Study models in rats would therefore certainly represent an advance in terms of cost and ease of performance. Thus it is important to know how similar the TMJ's of rats and humans are. Even though the results of this study cannot be extrapolated to humans because of species differences, they could give rise to new ideas on the treatment of a great number of diseases. The literature is scanty in this regard, since there has been no article published to date comparing the two joints.

Based on the results of this study it is possible to say that, with regard to the histopathological features, there is a great similarity between the rat and human TMJ's. As in the rat, in the human condyle there is a thick layer of cartilage, mainly of the hyliane type, but with more layers of superimposed condrocytes than on the articular surface of the rat condyle. The human temporal articular surface is also similar to that of the rat except for the smaller number of layers of condrocytes as well as the greater thickness of the fibrous layer. The shape of the disc is also similar, since the rat's disc is biconcave and is made up of fibrous connective tissue, as is the human one. The rat's TMJ also contains a synovial membrane as does the human one. This paper did not study the quantitative variables of anatomic and histomorphometric measurements.

As far as anatomical features are concerned, it is important to point out that the size of the rat joint is much smaller than the human one, and the main difference between them is that there is no articular eminence in the rat TMJ. The position of the condyles is also divergent. In addition, the shape of the mandibular angle is different, since in the rats this angle is more prominent. The absence of the articular eminence may make the movement of the mandible highly specialized for extensive protrusive movements. The rounded condyle travels in a trough-like temporal fossa and the power stroke is in the protrusive direction with only a minor medial component ${ }^{1}$. Since the mandibular symphysis is fibrous, rotation of the long axis may occur around this mobile symphysis. Calculations indicate that neither the working nor the balancing side of the TMJ is loaded during mastication ${ }^{6,7}$.

With regard to the soft tissues, one may state that the parotid gland is smaller in the rat. There is a great similarity in the case of the facial nerve with its ramifications, a thick masseter muscle, an articular disc and capsule. 


\section{Conclusion}

Morphologically and histologically, the articular structure of rats is, on the whole, similar to that of humans. In these animals there is no articular eminence.

\section{References}

1. Siéssere S, Vitti M, Semprini M, Regalo SCH, Iyomasa MM, Dias FJ, Issa JPM, Sousa LG. Macroscopic and microscopic aspects of the temporomandibular joint related to its clinical implication. Micron. 2008;39(7):852-8.
2. Koolstra JH. Dynamics of the human masticatory system. Crit Rev Oral Biol Med. 2002;13(4):366-76.

3. Schek RM, Taboas JM, Hollister SJ, Krebsbach PH. Tissue engineering osteochondral implants for temporomandibular joint repair. Orthod Craniofac Res. 2005;8(4):313-9.

4. Cate ART. Oral histology: development, structure and function. 5 ed. St. Louis: Mosby-Year Book; 1998.

5. Herring SW. Animal models of TMJ research. J. Musculoskel. Neuron Interact. 2003;3(4):391-4.

6. Weijs WA. Mandibular movements of the albino rat during feeding. $\mathrm{J}$ Morphol. 1975;145(1):107-24.

7. Weijs WA, Dantuma R. Electromyography and mechanics of mastication in the albino rat. J Morphol. 1975;146(1):1-34.

\section{Correspondence:}

Prof. Dr. Belmiro Cavalcante do Egito Vasconcelos

Faculdade de Odontologia de Pernambuco (FOP/UPE)

Disciplina de Cirurgia e Traumatologia Buco-Maxilo-Facial

Av. Gal. Newton Cavalcanti, 1650

54753-220 Camaragibe - PE Brazil

Phone/Fax: (55 81)3458-2867

belmiro@pesquisador.cnpq.br

Conflict of interest: none

Financial source: none

Received: December 17, 2009

Review: February 12, 2010

Accepted: March 18, 2010 